\title{
TYPE 1 DIABETES MELLITUS PRESENTING AS DISTAL RENAL TUBULAR ACIDOSIS (RTA TYPE 1)
}

\author{
Mohit Garg ${ }^{1}$, Ravi Kant ${ }^{2}$ \\ ${ }^{1}$ Senior resident, Department of General medicine, AIIMS Rishikesh \\ ${ }^{2}$ Additional Professor, Department of General Medicine, AIIMS Rishikesh
}

\begin{abstract}
Background: Type 1 Diabetes Mellitus (DM) is an autoimmune process which causes destruction of b-cells and absolute insulin deficiency. This insulin deficiency prone patient to hyperglycemia and resultant early micro-vascular and macro-vascular complications. Macro-vascular complication seen early in diabetes are CAD, CVA and PAD. In micro-vascular complications, we have retinopathy, neuropathy and nephropathy. In diabetic nephropathy, usually glomerular injury is widely described in literature but little is known about the tubular changes. We report a case which has tubular damage in the form of distal tubular damage causing renal tubular acidosis. Patient has classical bilateral nephrocalcinosis, normal anion gap acidosis and persistently low HCO3. This entity in type $1 \mathrm{DM}$ is not reported in literature. Case : Patient S, 42 yr Male with Type 1 DM for 15 years on Inj. Insulin mixtard presented to emergency with swelling of bilateral lower limb associated with pain/tingling and numbness for 3 months. Conclusion: In a patient with type 1 DM, acidosis can occur due to causes other than DKA and workup should be done if acidosis persists even after treatment.
\end{abstract}

Abbreviations: DM(diabetes mellitus), HCO3(bicarbonate), RTA(renal tubular acidosis), CAD(coronary artery disease), CVA( cerebrovascular accident), PAD(peripheral artery disease).DKA(diabetic ketoacidosis)

\section{INTRODUCTION}

Type 1 Diabetes Mellitus (DM) is usually an auto-immune $^{1}$ process in which there is an immunological destruction of beta $(\beta)$ cell which causes absolute insulin deficiency. In absence of insulin deficiency, there is lactic acidosis which is a high anion gap metabolic acidosis. Patient with type 1DM generally presents with DKA (Diabetic ketoAcidosis) in which acidosis is due to high ketones in body. We present a case which has normal anion gap acidosis in type $1 \mathrm{DM}$ with uncontrolled hyperglycemia. Distal RTA commonly occur in condition like amyloidosis, Sjogren syndrome, SLE (Systemic Lupus Erythematosus) and Sickle cell diseases. Distal RTA presents as nephrocalcinosis, normal anion gap with hyperchloremic acidosis

Corresponding Author

Dr. Mohit Garg, 95, Laxmi Nagar, Khandwa (M.P.) 450001 mohit2503@gmail.com which occurs due to inability of distal convoluted tubule to produce hydrogen $(\mathrm{H}+)$ ions ${ }^{2}$. This in turn, leads to loss of $\mathrm{H}+$ ions and subsequently loss of potassium $(\mathrm{K})$ in the body causing hypokalemia and alkaline urine. This alkaline in urine causes precipitation of calcium stones in urine and patient presents as asymptomatic/ symptomatic nephrolithiasis.

\section{CASE REPORT}

Patient S, 42yr Male with Type 1 DM for 15 years on Inj. Insulin mixtard presented to emergency with swelling of bilateral lower limb associated with pain/tingling and numbness for 3 months. Swelling in bilateral lower limb was gradual, extending up to ankle. No history of pain abdomen, nausea, vomiting, chest pain, shortness of breath, syncope, palpitation, sweating, burning micturition or decreased urine output. No history of Hypertension, Tuberculosis, Asthma in past. Family history was 
also not significant. Patient left Inj. Insulin for the past 3 days due to unavailability. Patient was admitted and investigations were sent. Investigations at admissions were (Table 1):

\begin{tabular}{|l|l|l|}
\hline \multicolumn{3}{|c|}{ TABLE 1 } \\
\hline Date & $\mathbf{2 4 / 0 1 / 2 0 1 9}$ & $\mathbf{2 8 / 0 1 / 2 0 1 9}$ \\
\hline Hemoglobin & $7.49 \mathrm{~g} / \mathrm{dl}$ & \\
\hline Total Leucocyte Count & $11340 / \mathrm{mm} 3$ & \\
\hline Differential Leucocyte count & N89L5M5 & \\
\hline Platelets & $146 \mathrm{lakh} / \mathrm{mm} 3$ & \\
\hline Hematocrit & 23.7 & $22 \mathrm{mg} / \mathrm{dl}$ \\
\hline Blood Urea & $81 \mathrm{mg} / \mathrm{dl}$ & $0.96 \mathrm{mg} / \mathrm{dl}$ \\
\hline Serum creatinine & $1.96 \mathrm{mg} / \mathrm{dl}$ & $137 \mathrm{mEq} / \mathrm{L}$ \\
\hline Serum sodium & $124 \mathrm{mEq} / \mathrm{l}$ & $3.2 \mathrm{mEq} / \mathrm{L}$ \\
\hline Serum K & $5.5 \mathrm{mEq} / \mathrm{L}$ & $106 \mathrm{mEq} / \mathrm{L}$ \\
\hline Serum Chloride & $98 \mathrm{mEq} / \mathrm{L}$ & $7.7 \mathrm{mg} / \mathrm{dl}$ \\
\hline Serum Calcium & $7.6 \mathrm{mg} / \mathrm{dl}$ & $3.4 \mathrm{mg} / \mathrm{dl}$ \\
\hline Serum Phosphorus & $3.9 \mathrm{mg} / \mathrm{dl}$ & \\
\hline Total bilirubin & $0.46 \mathrm{mg} / \mathrm{dl}$ & \\
\hline Direct bilirubin & $0.12 \mathrm{mg} / \mathrm{dl}$ & \\
\hline SGPT & $15 \mathrm{U} / \mathrm{L}$ & \\
\hline SGOT & $36 \mathrm{U} / \mathrm{L}$ & \\
\hline ALP & $168 \mathrm{U} / \mathrm{L}$ & \\
\hline Total Protein & $5.3 \mathrm{gm} / \mathrm{dl}$ & \\
\hline Albumin & $3.2 \mathrm{gm} / \mathrm{dl}$ & \\
\hline Globulin & $2.1 \mathrm{gm} / \mathrm{dl}$ & \\
\hline pH & 7.32 & \\
\hline HCO3 & $11.1 \mathrm{mEq} / \mathrm{L}$ & \\
\hline Anion gap & $11 \mathrm{mEq} / \mathrm{L}$ & \\
\hline RBS & High & \\
\hline HbA1C & 12.7 & \\
\hline Urine R/M & Glucose ++, protein + and ketones absent & \\
\hline & & \\
\hline
\end{tabular}

Patient was managed on the line of DKA with Intravenous fluids and insulin as the patient had very low bicarbonate (HCO3) and high dextrose. During 2-day course, patient ABG showed persistent low $\mathrm{HCO} 3$ in spite of blood sugar being controlled, so cause of persistent acidosis other than DKA was sought, urine $\mathrm{pH}$ was advised which came out to be 6.0 .

Patient was evaluated for causes of low HCO3 with high urinary pH. USG (ultrasound) abdomen was suggestive of multiple hyperechoic calculi seen in upper pole with largest measuring $7.8 \mathrm{~mm}$ in the right kidney. Left kidney size normal with multiple hyperechoic calculi in lower pole and posterior pole longest $9 \mathrm{~mm}$. Ophthalmology evaluation suggested bilateral moderate Non Proliferative Diabetic Retinopathy (NPDR). Patient repeat investigations were (Table 2): 


\begin{tabular}{|l|l|l|l|}
\hline \multicolumn{4}{|c|}{ TABLE 2 } \\
\hline Date & $\mathbf{2 8 / 0 1 / 2 0 1 9}$ & $\mathbf{3 0 / 0 1 / 2 0 1 9}$ & $\mathbf{0 4 / 0 2 / 2 0 1 9}$ \\
\hline Urine pH & 6.0 & 6.0 & 6.0 \\
\hline Urine R/M & $\begin{array}{l}\text { Glucose-nil, protein-nil, } \\
\text { ketone-nil }\end{array}$ & Protein + ,glucose-nil & Proteins +, glucose - nil \\
\hline pH & 7.29 & 7.41 & \\
\hline HCO3 & $15.6 \mathrm{mEq} / \mathrm{L}$, & 18.8 & \\
\hline Anion Gap & $9 \mathrm{mEq} / \mathrm{L}$ & $5 \mathrm{mEq} / \mathrm{L}$ & \\
\hline iPTH & $14.9(11-79)$ & & \\
\hline
\end{tabular}

Patient had kidney stones despite serum calcium to be low. iPTH was advised due to low calcium which also lies in the lower range, ruling out secondary hyperparathyroidism. We searched literature for the same and most common cause for this presentation was distal RTA.

\section{DISCUSSION}

Type $1 \mathrm{DM}$ is a chronic autoimmune disease beginning with genetic susceptibility and progressing to autoimmunity leading to destruction of $\beta$-cells. Autoantibodies against the pancreatic islet, islet cell antibodies (ICA) and Glutamic acid decarboxylase (GAD) are detected in childhood in these patient ${ }^{3}$. It is usually a disease of childhood/ young. According to 2009 census, 6666 of 3.4 million youth were diagnosed with type 1 diabetes for a prevalence of 1.93 per 1000 . The highest prevalence of T1D was 2.55 per 1000 among white youth and the lowest was 0.35 per 1000 in American Indian youth ${ }^{4}$.

DistalRTAis a syndrome of systemic hyperchloremic acidosis with alkaline urine $\mathrm{pH}$, hypocitraturia and hypercalciuria due to reduced secretion of $\mathrm{H}+$ ions by the cells of the collecting tubules ${ }^{5,6}$. Metabolic acidosis in distal RTA contributes as a predisposing factor to recurrent nephrolithiasis and bone $\operatorname{loss}^{6}$. Patients with distal RTA are unable to lower urine $\mathrm{pH}$ normally in the presence of systemic metabolic acidosis regardless of its severity ${ }^{7}$.

15-30\% of subjects with type 1 DMhave autoimmune thyroid disease, 4-9\% have celiac disease, and
$0.5 \%$ have Addison's disease ${ }^{3}$. Distal RTA is also multifactorial, it can develop as a consequence of autoantibodies, most commonly in Sjögren's syndrome and systemic lupus erythematosus(SLE). There are various case reports which has linked distal RTA with autoimmunity and destruction of collecting ducts ${ }^{8}$. There are only few case reports with patients of type 1 DM developing distal RTA, in which one patient having due to autoimmune and other patient is having Sjogren syndrome ${ }^{9-10}$ and no cause could be found in some other ${ }^{11}$.

Our patient had all features of distal RTA in the form of nephrocalcinosis, acidic urine, low bicarbonate, metabolic acidosis which persisted even after correction of blood sugar. He had proteinuria and slightly deranged creatinine, also had retinopathy which favours nephropathy. But destruction of glomeruli alone cannot explain the development of distal RTA in our patient. Various studies previously had already shown that diabetic patients have interstitial and tubular injury along with glomerular injury ${ }^{12-14}$.

Additional investigations in the form of kidney biopsy would be required for further confirmation of the cause of destruction of collecting ducts Tubular damage.

Distal RTA improved with alkali therapy and it also prevent the formation of renal stones. Our patient already has developed renal stones, still alkali therapy will prevent the progression of stones. We thus present a case which was unusual 
in T1D as every type 1DM doesn't have acidosis due to DKA. Also, patients with hypokalaemia and nephrocalcinosis, we should rule out causes and extensive investigations are required for confirmation of diagnosis. Further research is required in this field.

\section{CONCLUSION}

Type 1 DM patients are prone for autoimmune diseases but we should think beyond autoimmunity in type $1 \mathrm{DM}$ as they may develop disease which may be complications of DM per se. Acidosis in type $1 \mathrm{DM}$ is not always due to DKA and we should search for other causes of persistent acidosis.

We have taken a written consent from the patient for the publication of this case report. There is no conflict of interest between the authors. This research has not received any specific grant from any funding agency in public, commercial or notfor-profit sector.

\section{References}

1) Atkinson MA, Eisenbarth GS, Michels AW. Type 1 diabetes. Lancet. 2014 Jan 4;383(9911):69-82.

2) Both $T$, Zietse R, Hoorn EJ, van Hagen PM, Dalm VA, van Laar JA, van Daele PL. Everything you need to know about distal renal tubular acidosis in autoimmune disease. Rheumatol Int. 2014 Aug;34(8):1037-45.

3) Barker JM. Clinical review: Type 1 diabetesassociated autoimmunity: natural history, genetic associations, and screening. J Clin Endocrinol Metab. 2006 Apr;91(4):1210-7.

4) Dabelea D, Mayer-Davis EJ, Saydah S, Imperatore $\mathrm{G}$, Linder $\mathrm{B}$, Divers $\mathrm{J}$, Bell R, Badaru A, Talton JW, Crume T, Liese AD, Merchant AT, Lawrence JM, Reynolds K, Dolan L, Liu LL, Hamman RF; SEARCH for Diabetes in Youth Study. Prevalence of type 1 and type 2 diabetes among children and adolescents from 2001 to 2009. JAMA. 2014 May 7;311(17):1778-86.

5) Hess B (2006) Acid-base metabolism: implications for kidney stones formation. Urol
Res 34(2):134-138.

6) Arampatzis S, Röpke-Rieben B, Lippuner $\mathrm{K}$, Hess B. Prevalence and densitometric characteristics of incomplete distal renal tubular acidosis in men with recurrent calcium nephrolithiasis. Urol Res. 2012 Feb;40(1):53-9.

7) Batlle DC, Sehy JT, Roseman MK, Arruda JA, Kurtzman NA. Clinical and pathophysiologic spectrum of acquired distal renal tubular acidosis. Kidney Int. 1981 Sep;20(3):389-96.

8) Konishi K, Hayashi M, Saruta T. Renal tubular acidosis with autoantibody directed to renal collecting-duct cells. N Engl J Med. 1994 Dec 8;331(23):1593-4.

9) Maeng M, Pedersen KM. A young woman with metabolic acidosis and recently discovered IDDM without ketouria. A rare autoimmune (?) combination of hypothyroidism, diabetes mellitus and distal tubular acidosis. Ugeskr Laeger 1998; 21; 160: 5663-5664.

10) Raddatz V, Alvo M, Durruty P, Orellana L, Garcia de los Rios M. Decompensated diabetes mellitus and hyperchloremic metabolic acidosis: a case with both pathologies. Rev Med Chil 1998; 126: 1224-1228.

11) Dymot JA, McKay GA. Type 1 (distal) renal tubular acidosis in a patient with Type 1 diabetes mellitus--not all cases of metabolic acidosis in Type 1 diabetes mellitus are due to diabetic ketoacidosis. Diabet Med. 2008 Jan;25(1):1145.

12) Gilbert RE, Cooper ME. The tubulointerstitium in progressive diabetic kidney disease: more than an aftermath of glomerular injury? Kidney Int. 1999 Nov;56(5):1627-37.

13) Magri CJ, Fava S. The role of tubular injury in diabetic nephropathy. Eur J Intern Med. 2009 Oct;20(6):551-5.

14) Zeni L, Norden AGW, Cancarini G, Unwin RJ. A more tubulocentric view of diabetic kidney disease. J Nephrol. 2017 Dec;30(6):701-717. 